\title{
Labyrinthe
}

2| 1999

Numéro 2

\section{Les Innocents de Jack Clayton : invisible et secret au cœur de l'image}

\section{Marie-Pierre Frappier}

\section{(2) OpenEdition \\ 12 Journals}

\section{Electronic version}

URL: http://journals.openedition.org/labyrinthe/362

DOI: $10.4000 /$ labyrinthe.362

ISSN: 1950-6031

\section{Publisher}

Hermann

\section{Printed version}

Date of publication: 15 January 1999

Number of pages: $76-96$

\section{Electronic reference}

Marie-Pierre Frappier, "Les Innocents de Jack Clayton : invisible et secret au cœur de l'image », Labyrinthe [Online], 2 I 1999, Online since 04 March 2005, connection on 22 April 2019. URL: http:// journals.openedition.org/labyrinthe/362 ; DOI : 10.4000/labyrinthe.362

This text was automatically generated on 22 April 2019

Propriété intellectuelle 


\section{Les Innocents de Jack Clayton: invisible et secret au cour de l'image}

Marie-Pierre Frappier 